\title{
Factors Determining Usability of the Streets
}

\author{
Norhafizah Abdul Rahman ${ }^{1}$, Shuhana Shamsuddin², \\ Izham Ghani ${ }^{1}$ \\ 1 Department of Landscape Architecture, \\ Universiti Teknologi MARA, Seri Iskandar 32610, Malaysia \\ 2 UTM Razak School of Engineering and Advanced Technology, \\ Universiti Teknologi Malaysia, Kuala Lumpur 54100, Malaysia \\ norha776@perak.uitm.edu.my, shuhana.kl@utm.my, izham025@perak.uitm.edu.my
}

\begin{abstract}
This paper examines the factors that make people use the street in Kuala Lumpur city centre. The study employed a mix-methodology method. The results suggest that the needs of users on the street depend on various factors, such as attractions; activities and reasons; proximity, lack of congestion; familiarity and length of engagement with the place public space. The findings show that, in general, the factors that make people use the street are mostly similar with previous theories. However, the attributes that contribute to the influencing factors vary for each context.
\end{abstract}

Keywords:Uses and activities; pedestrians need; public spaces; liveable street

eISSN 2398-4295 @ 2018. The Authors. Published for AMER ABRA cE-Bs by e-International Publishing House, Ltd., UK. This is an open-access article under the CC BY-NC-ND license (http://creativecommons.org/licenses/bync-nd/4.0/). Peer-review under responsibility of AMER (Association of Malaysian Environment-Behaviour Researchers), ABRA (Association of Behavioural Researchers on Asians) and cE-Bs (Centre for EnvironmentBehaviour Studies), Faculty of Architecture, Planning \& Surveying, Universiti Teknologi MARA, Malaysia.

DOI: http://dx.doi.org/10.21834/ajbes.v3i12.136 


\subsection{Introduction}

Streets are an important component of the urban form and the most public of the urban spaces in the city. Lack of understanding in urban design and peoples' need in urban space development had led to a reduction in public spaces and resulted in urban spaces not being friendly to their users. The rapid growth and construction in the cities have tremendously influenced the relationship between the urban users and the social spaces. This issue constitutes one of the most important concerns in Kuala Lumpur city centre. It was highlighted that the increase in population has contributed to the decrease in the quality of the urban environment and the quality of life of the inhabitants. Therefore, the streets will become a vital space for the public and need to be governed effectively and efficiently to promote an environment that is conducive, sustainable and friendly to all (Rahman et al., 2012).This paper examines the factors that make people used the street which lead to a liveable urban environment in Kuala Lumpur city centre.

\subsection{Literature Review}

Liveability is the physical quality that is required in order to make a great street and does affect the uses of the street (Jacobs, 1996). The degree of liveliness and form is influenced by many factors. The character of the street varies according to the purpose and function of the location, physical form and appearance, socioeconomic and cultural characteristics of the user as well as the inhabitant. This may affect the needs and perceptions of the users that might be different from other street users in other countries (Appleyard, 1981; Wan Ismail, 2010).

The role of human aspects is established as an important framework for good urban space. A good or bad urban space can be judged by the people who use and involved with the space. Nowadays, the human dimension has been overlooked and not seriously addressed in urban design compared to other issues, such as accommodating the increase of cars in urban areas (Gehl, 2010).

Pedestrian activities on the street are important to review because the need of users in the street depends on their activities and reasons of use. Gehl (1987) argued that the categories of outdoor spaces are influenced by the quality and the character of the outdoor spaces. He adds that the activities and functions will be developed when the qualities of the space are improved. These activities vary greatly by culture, where some activities in some countries would not be acceptable in another country. As supported by Shamsuddin (2011), cultural values affect the behaviour in the streets and reflect the direct pedestrian response to the environment. In order for the street to be used by people, the street should be designed to suit the activities. Davies (2000), suggested that if the street is a commercial street, the design should enable users to get to the shop, cross the road and have other static and leisure activities, such as chatting and lingering in front of shop windows. A mixture of activities and use can create a successful community and public space that enables the street to attract more people to come (Shamsuddin ,2011; Shohoohi et al, 2012).

The most important design criterion for a liveable street is comfort which is one of the basic human needs in urban spaces (Carr et al., 1992; Jacobs,1996; Carmona et al, 2003). 
In a hot and humid country like Malaysia, environmental conditions in public spaces play a vital role in creating a comfortable space. In order to create comfortable street, the design decisions play an important role in modifying the impact of microclimate (Carmona et al., 2003; Mofidi, 2009).

\subsection{Methodology}

This study involves a mixed method approach where analysis was done on both quantitative and qualitative data. The street environment is examined in respect of the physical qualities through the analysis of questionnaire surveys, interviews and observations of the users' activities as well as the physical environment of the street. The analysis of questionnaire surveys of 340 respondents was selected using quota sampling. The criteria for the survey area selection are based on its location within the urban centre as well as their social demographic backgrounds.

An interview with a small group of urban users was conducted to probe on issues highlighted in the survey in order to determine the influence of the outdoor environment on the pedestrian behaviour. A convenience random sampling of 20 street users was interviewed. The in-situ interviews will assure that the respondent's phenomenological observations are recorded and that the perceptions while moving could be considered in the final outcome. In this study, structured observations of the users' activities and physical environment of the street was conducted as part of the multi method approach to record the physical characteristics and the qualities in urban pedestrian environments and to study human activities on the streets. Field observations and documentation of the quality of the site in the form of maps and photographic records were conducted for each sub-area of the case study. Field notes and related photographs were taken to examine the users' interactions with the physical settings, features and others.

A triangulation method and cross analysis between different techniques and the literature review was conducted to identify the problems relating to outdoor urban environment that influence the pedestrians' behaviour. The data were processed using both qualitative and quantitative approaches and tabulated to seek potential patterns and connections.

\subsection{Results and Discussions}

Based on the results from the survey at Jalan Tunku Abdul Rahman (JTAR), Kuala Lumpur, there are four main factors that make people used the streets which are: attractions on the street, activities, commute distance (proximity) and congestion.

\subsection{Attractions on street}

In this study, attraction was shown to be an important factor that can persuade people to use the street. Attraction or desirability is related to the qualities engaged with by the eyes, aesthetic values and entertainment quality. Users do not always simply choose the most obvious route to reach their destination; they are also influenced by how interesting or dull each route is (Gehl, 2000). This is also supported by Tibbalds (1992), who stressed the importance of attractive public spaces in urban areas in producing a feeling of comfort or 
well-being to the users. The results from this study show that functional factors were the strongest form that contributed to the use of the street rather than physical factors. Based on the survey, the top functional attractions according to the users in JTAR were shopping centres and as the best place to earn money (Table 1).

Table 1: The main attractions in JTAR by different groups of users

\begin{tabular}{|c|c|c|c|c|c|c|c|}
\hline \multirow{2}{*}{$\begin{array}{l}\text { Main } \\
\text { attraction }\end{array}$} & \multicolumn{2}{|c|}{ Type of use (\%) } & \multicolumn{2}{|c|}{ Gender (\%) } & \multicolumn{3}{|c|}{ Ethnicity (\%) } \\
\hline & Occasional & Daily & Male & Female & Malay & Chinese & Indian \\
\hline $\begin{array}{l}\text { Shopping } \\
\text { centres }\end{array}$ & 59.1 & 37.9 & 43.6 & 46.6 & 45.7 & 38.7 & 50.0 \\
\hline $\begin{array}{l}\text { Best place } \\
\text { to earn } \\
\text { money or } \\
\text { income }\end{array}$ & 18.3 & 37.7 & 22.7 & 24.1 & 22.3 & 27.4 & 21.9 \\
\hline $\begin{array}{l}\text { Public } \\
\text { facilities }\end{array}$ & 7.0 & 14.8 & 12.7 & 11.2 & 10.9 & 9.7 & 21.9 \\
\hline $\begin{array}{l}\text { Public } \\
\text { spaces, } \\
\text { buildings } \\
\text { and } \\
\text { landscapes }\end{array}$ & 13.2 & 13.3 & 11.1 & 18.1 & 21.1 & 24.2 & 0.2 \\
\hline Total & 100.0 & 100.0 & 100.0 & 100.0 & 100.0 & 100.0 & 100.0 \\
\hline
\end{tabular}

(Source: Authors)

Apart from shopping and being the best place to earn money and income, the physical environment, such as the public spaces, buildings and landscape also contributes as one of the attractions in JTAR. The results show that main physical attractions in JTAR are public facilities and public spaces. These types of attraction are related to 'the feeling of relaxation'; leisure and aesthetic value (Jacobs, 1996). It was found in the survey that different groups of user are attracted to JTAR for different reasons. This is because their intentions and reasons for using the street, as well as their activities and how they use the street may affect their attraction to the area. The familiarity, time spent, and frequency of visits to JTAR were different between users, which meant that their criteria of attraction towards the place were dissimilar between each group.

\subsection{Activities on street}

The results from the surveys and in-depth interviews indicated that, the functional factors were the main factors that influence the use of the street. Based on observations on the site even though there are different types of development, the most vital generators are business 
and commercial activities. Responses from the interviews indicate that a variety of choices, diversity of products and distinctive products that they can get from this street make them love to shop here. The second significant purpose for being in JTAR according to the respondents was meeting friends. Based on the observation on site, people meet friends together while enjoying foods in restaurants or during shopping. The presence of outdoor cafes and restaurants that provide wireless Internet and air conditioning make the place suitable as a meeting place.

A pleasing environment is one of the sub factors that can attract activities onto the street. The results of the survey concerning the degree of visually pleasing places in JTAR showed that there was a positive response from users' perceptions concerning the quality. This shows that visually pleasing place is one of the factors that can attract people to use the street. This was proved by Gehl (2010) that there is a strong connection between the qualities of the physical environment on site. The understanding of the activities that occur in the street is important to generate new ideas and also for proposing new development. This is in line with Shamsuddin et al. (2010), who stressed that designers are should look into the activities in the urban spaces in order to exploit for future design.

\subsection{Proximity (commute distance)}

The proximity or commute distance from the user's place of work and home is one of the most important factors influencing the use of the street. Results from survey showed that the shorter the distance, the more often they used the street. The perceived distance can be influenced by the right type of land use and design characteristics. Based on observations it was found that design element such as continuous walking systems that connect door fronts with transit stops or other destinations can create good connections. The proximity of public transport and shopping spots make this street highly accessible for pedestrians.

The presence in proximity in JTAR contributes to accessible street that gives pedestrians comfort of the street. This aspect will help the street users to move between and within the zones (Anderson, 2006). Burton et al. (2006) noted that ten minutes (about 800 metres) is a comfortable walking time for people to reach services and facilities. Therefore, the locations for the services and facilities, such as shops, public transport and other facilities should be located or situated within a 10 minutes walking distance (Burton et al., 2006). However, in some situations even though pedestrians aim to use the shortest route, due to encounters with other pedestrians and obstacles on the street they might not be able to do so.

\subsection{Congestion}

Congestion in this study can be divided into traffic congestion and pedestrian congestion, which contribute to the reasons why they avoid using JTAR. It was proven by the results from the questionnaire survey that congestion is one of the factors why the users do not use the street. Based on the survey concerning improvements needed to JTAR, all types of user suggested reducing congestion on the street as the highest priority (Figure 1). People congestion makes people feel uncomfortable and unsafe to use the street which contributes to the feeling of stress (Krupart, 1985). This is proven by the respond from many respondents 
in the interviews who mentioned that people congestion contributes to the feeling of being uncomfortable and unsafe. In JTAR, the feeling of crowding was also caused by the speed of the pedestrians. People who walk along this street tend to walk much slower for the purpose of shopping compared to other purposes. This was because the shoppers tend to stroll, stop to look in windows, travel with children and carry luggage (Al-Azzami, 2004).

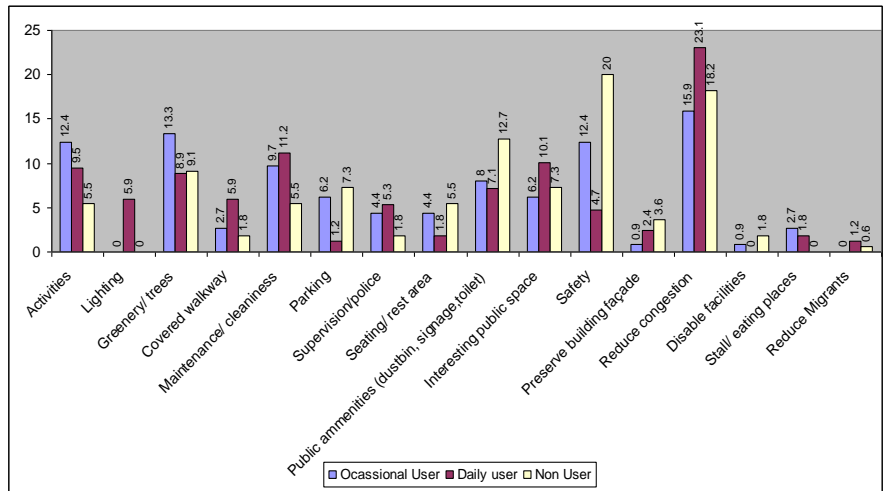

Figure 1: Respondents' suggestions concerning the most needed improvements in JTAR (Source: Authors)

In summary, crowded streets and peoples' eyes produce a sense of belonging and turn the cities into stages; however if they were too congested people may feel uncomfortable and unsafe. However, the feeling of crowding is different for each of the user.

\subsection{Familiarity and length of engagement}

The more familiar people are with the place the safer they feel with the environment. Familiarity with shopping streets closely reflects the user's ability to identify locations and elements associated with it (Ujang, 2008, 2010). Users who are more familiar with the street felt safer alone compared to the group of users that are not familiar with the street studied. The results from the interviews reveal that users who use the street more often tend to indicate more positive feelings concerning safety and security, and have a less positive feeling for satisfying the environments. This shows that familiarity and frequent engagement with the street make the street friendlier to users by developing a greater sense of belonging and strong emotional feelings about the place.

\subsection{Conclusion}

The purpose of this paper is to determine the design criteria of a liveable street. In this study it was revealed that the design criteria that contribute to liveable street in Malaysian context were mostly aligned with previous theories. There was also not much difference between the user needs of a user-friendly street with the needs of users of other urban spaces in previous theories. However, the attributes that contribute to the factors vary for each context especially 
for countries with different climate and economic level (between developing and developed countries). This may relate to the environment, climate or culture of the place, which is different from previous studies. This identifies the factors that need to be considered in future guidelines and policies for planning and design in urban spaces especially in streets. It is hoped that these factors will be taken into consideration by those involved with decision makers with respect on future urban design guidelines.

\section{Acknowledgement}

The authors are grateful to the Ministry of Higher Education (Malaysia) and Universiti Teknologi MARA for sponsoring this research. The authors would also like to thank the following organisations; Dewan Bandaraya Kuala Lumpur (DBKL) and Jabatan Perancangan Bandar dan Desa (JPBD) for their contributions in the completion of this research.

\section{References}

Appleyard, D. (1981). Livable streets. London: University of California Press.

Carmona, M., Heath, T., Oc, T., \& Tiesdell, S. (2003). Public places, urban spaces: The dimensions of urban design. London: Architectural Press.

Davies, L.( 2000). Urban Design Compendium, English Partnership UK.

Gehl, J. (2010). Cities for people. Washington: Island Press.

Jacobs, A. B. (1996). Great streets. Cambridge, Massachusetts: The MIT Press.

Mofidi, S. M. (2009). Principles and parameters of sustainable urban built form for temperate regions. In S. M. Fortea \& J. Al-Qawasmi (Eds.), Sustainable architecture and urban development (pp. 81-96): CSAAR Press.

Krupart, E. (1985). People in Cities: The Urban Environment and its effects, Cambridge University Press, New York.

Rahman, N. A, Shamsuddin,S., \& Ghani,I. (2014). What makes people use the street?: Towards a liveable urban environment in Kuala Lumpur city centre, Procedia- Social and Behavioural Sciences, Vol 170,624-632

Rahman, N. A, \& Sakip, S. R. M. (2014). Relationship between accessibility and safety criterias with the uses of the street: A case study of urban commercial street in Kuala Lumpur city centre, Researchgate.net

Rahman, N. A. (2013). User-friendly street in Malaysia. University Of Nottingham, UK, Unpublished Ph.D. thesis.

Rahman, N. A., \& Shamsuddin, S. (2010). User perceptions towards street characteristics and qualities that contribute to user-friendly street. Paper presented at the 3rd Arte-Polis International Conference on Creative Collaboration and the Making of Place: Learning from Shared Creative Experiences, ITB's School of Architecture, Planning and Policy Development, Bandung, Indonesia.

Rahman, N. A., Shamsuddin, S., \& Heath, T. (2012). Peoples' choices and behaviour in urban streets. Paper presented at the International Conference on Innovation and Technology for Sustainable Built Environment, UiTM Perak, Malaysia. 
Rapoport, A. (1986). The use and design of open spaces in urban neighborhoods. In A. Rapoport \& D. Frick (Eds.), The quality of urban life (pp. 159-175). New York: Walter de Gruyter \& Co.

Shamsuddin, S., Abdul Rahman, N., \& Sulaiman, A. B. (2010). How walkable is our city? Its influence in creating sustainable city centre design Paper presented at the International Conference Sustainable Architecture \& Urban Design 2010, Universiti Sains Malaysia, Malaysia.

Shamsuddin, S., Sulaiman, A. B., Ja'afar, N. H., \& Noor, M. M. (2004). Criteria for successful traditional shopping streets in Malaysia : A case study of Kuala Lumpur. Skudai: Universiti Teknologi Malaysia.

Shohoohi,R.,Rosly,N.,\& Dali,M. (2012). Influence of the socio-economic factors on children's school travel ProcediaSocial and Behavioural Sciences, 50(2012), 135-147.

Tibbalds, F. (1992). Making people-friendly towns: Improving the public environment in towns and cities. Harlow: Longman.

Ujang, N. (2008). Place attachment and users perceptions of Kuala Lumpur city centre: University Putra Malaysia.

Ujang, N. (2010). Place attachment and continuity of urban place identity. Procedia- Social and Behavioural Sciences, 2(0), 62-76. 